УДК 342

DOI https://doi.org/10.32849/2663-5313/2020.6.19

Ольга Безпалова,

докт. юрид. наук, професор, заслужений діяч науки і техніки Украйни, завідувач кафедри полічейської діяльності та публічного адміністрування факультету № 3

Харківського начіонального університету внутрішніх справ

\title{
СУТНІСТЬ ТА ЗНАЧЕННЯ КООРДИНАЦІЙНИХ ОРГАНІВ ЯК СУБ'ЄКТІВ РЕАЛІЗАЦІї ДЕРЖАВНОЇ ПОЛІТИКИ
}

У статті встановлено, що основним призначенням діяльності координаційних органів є упорядкування діяльності органів виконавчої влади щодо реалізаиії державної політики у відповідних сферах суспільного життя. Наведено приклади таких координаційних органів та сфери, для забезпечення належного функиіонування яких вони мають право реалізовувати координаиійні заходи. У результаті аналізу нормативно-правових актів, в яких окреслено коло повноважень координаційних органів, визначено коло заходів, які вказані органи уповноважені вживати під час реалізаиї̈ державної політики. Визначено, що під координаційними органами слід розуміти органи державної влади (інституиії), наділені нормами начіонального адміністративного законодавства повноваженнями щодо узгодення діяльності учасників прочесу управління в окремих сферах суспільного життя шляхом упорядкування їх взаємозв'язків та взаємодії у напрямі об'єднання зусиль для вирішення спільних завдань. З'ясовано, що головною метою діяльності координаційних органів є підвищення якісних характеристик рішень, що спільно розробляються і виконуються органами влади та орієнтовані на досягнення заданих результатів. Для досягнення поставленоїмети кожен учасник координаційних заходів застосовує в рамках наданої йому компетениї форми та методи в одному узгодженому напрямі спільно з іншими органами. Зроблено висновок, що основними ознаками діяльності координаційних органів як суб'єктів реалізаиї̈ державної політики є таке: врегульована нормами адміністративного законодавства (має правовий характер); узгоджуються дії суб'єктів спільної діяльності за иілями, часом, місием проведення, коло виконавиів та програма заходів з урахуванням компетенцї кожного виконавия; характеризується наявністю проиесуально-процедурних аспектів; зумовлена об'єктивними потребами, здійснюється на постійній основі в інтересах суспільства та держави в иілому; здійснюється спечіально уповноваженими на те суб'єктами по відношенню до тих учасників, що не перебувають у відносинах прямого підпорядкування з координуючим суб'єктом; здійснюється в чітко визначених формах та способах у межах повноважень координуючого суб'єкта.

Ключові слова: координація, взаємодія, функція управління, координаційні органи, координаційні заходи, суб'єкти, державна політика

Постановка проблеми. Наявність ефективної системи державного управління є необхідною передумовою для демократичного врядування, забезпечення подальшого курсу нашої держави на європейську інтеграцію шляхом приведення системи державного управління у відповідність до європейських стандартів належного управління державою. У зв'язку з цим 3 метою забезпечення функціонування ефективної системи державного управління великого значення набуває створення умов для діяльності усіх суб'єктів державного управління, забезпечення їх внутрішньої та зовнішньої комунікації, досягти чого можливо через упорядкування управлінських процедур та налагодження конструктивного діалогу. Зважаючи на те, що суб'єкти $є$ ключовим системоутворюючим елементом механізму реалізації державної політики у будь-якій сфері суспільного життя, надзвичайно актуальним є з'ясування їх вичерпного переліку, окреслення кола їхніх повноважень, вироблення дієвого механізму їх взаємодії. Це зумовлено таким: зважаючи на те, яким чином зазначені суб'єкти реалізовують надані їм повноваження, наскільки неупереджено та своєчасно вони виконують покладені на них обов'язки, наскільки ефективно налагоджена взаємодія між ними, залежить досягнення кінцевої мети (бажаного соціального ефекту) [1, с. 59]. Особливої уваги заслуговує питання не лише налагодження взаємодії між відповідними суб'єктами реалізації державної політики, а й упорядкування діяльності тих суб'єктів, що наділені координаційними повноваженнями, тобто здійснюють керуючий 
цілеспрямований вплив на діяльність окремих суб'єктів, які вирішують спільні завдання.

Стан дослідження. Варто звернути увагу, що питанням формування та реалізації державної політики як на загальнотеоретичному рівні (у тому числі з використанням здобутків науки адміністративного права), так і в різних сферах суспільного життя присвятили свою увагу такі вчені, як В. І. Андріяш, О. І. Безпалова, Ю. В. Ковбасюк, А. В. Малько, О. В. Минькович-Слободяник, В. В. Субочев, П. Л. Фріс, В. О. Хвалєєв, Ю. С. Шемшученко, К. В. Шундиков та ін. Вказаними науковцями грунтовано розкрито сутність та значення державної політики, розроблено механізм формування та реалізації такої політики, окреслено коло суб'єктів, відповідальних за ії формування та реалізацію як на загальнодержавному, так і на регіональному рівнях. Проте питання класифікації суб'єктів реалізації державної політики було не досить опрацьовано, оскільки в наявних наукових працях практично не приділялася увага суб'єктам реалізації державної політики, що наділені функцією координації. Відповідно ж до Стратегії реформування державного управління України на період до 2021 року одним з основних напрямів діяльності органів державної влади в системі державного управління є стратегічне планування, координація формування і реалізації політики [2]. Таким чином, зважаючи на те, що саме завдяки діяльності вказаних суб'єктів упорядковується діяльність інших учасників процесів управління в усіх сферах суспільного життя, дослідження сутності та особливостей координаційних органів, що виступають у ролі суб'єктів реалізації державної політики, набуває великого значення.

Метою статті $є$ визначення сутності координаційних органів як суб'єктів реалізації державної політики, кола їхніх повноважень та характерних ознак, притаманних їхній діяльності.

Виклад основного матеріалу. Перш за все варто зазначити, що найбільш поширеними формами спільної діяльності органів державної влади є взаємодія та координація. Дані терміни не $є$ словами-синонімами, оскільки несуть у собі різне змістове навантаження. Так, під взаємодією переважно розуміють взаємозв'язок між двома (або більше) суб'єктами, у ході якого відбувається реалізація спільних узгоджених за місцем та часом заходів, спрямованих на досягнення спільної мети. У юридичній літературі під терміном «взаємодія» розуміється: а) глибоке поняття, до якого входять спілкування, зв'язок і взаємодопомога у виконанні спільних завдань; планомірне та спільне здійснення комплексу спільних узгоджених дій у межах певного напряму співпраці [3, с. 110]; б) спільна дія, тобто взаємний зв'язок між предметами у дії, а також погоджена дія між ними [4, с. 623-624]. Є. Ю. Бараша пропонує термін «взаємодія» розглядати у широкому та вузькому сенсі. Так, у широкому сенсі взаємодія - це співпраця, яка полягає у спільних узгоджених діях, спрямована на досягнення спільної мети в наданні взаємної допомоги, наприклад під час ліквідації наслідків пожежі [5, с. 130]. У вузькому ж сенсі взаємодія полягає в планомірному здійсненні комплексу заходів під час проведення конкретних профілактичних заходів, наприклад інформаційні повідомлення в засобах масової інформації щодо дотримання правил пожежної безпеки [5, с. 130].

Що ж стосується координації, то вона $€$ однією із функцій управління, зміст якої полягає в забезпеченні впорядкування взаємозв'язків між учасниками процесу управління з метою узгодження дій та об'єднання зусиль для вирішення спільних завдань. Координація (від лат. coordinatio - розташування у порядку) - «...як управлінська функція $є$ складовою частиною процесів управління, що полягає в узгодженні, впорядкуванні дій різних частин керованої системи» [6]. У словниковій літературі «координація» трактується як функція управління, змістом якої є забезпечення упорядкованих взаємозв'язків і взаємодії між організаціями, ділянками та учасниками виробництва й управління 3 метою узгодження дій щодо реалізації рішень, об'єднання спільних зусиль у вирішенні загальних завдань [7, с. 76-77]. 3 позиції управлінської діяльності координація є заснованим на законі і підзаконних актах управлінським впливом вищого рівня суб'єктів стосовно нижчого рівня, що здійснюється з метою спрямування діяльності взаємодіючих підсистем на виконання загальних завдань при самостійному, автономному вирішенні [8]. 3 погляду В. Т. Білоуса, координація - це самостійний засіб організації управління, що пристосовується до забезпечення узгодження функціонування автономних цілеспрямованих систем $[9$, c. 65$]$.

Таким чином, основна відмінність взаємодії від координації полягає у тому, що остання передбачає наявність керуючого (владного) цілеспрямованого впливу координуючого органу системи, що спрямовує діяльність окремих суб'єктів на виконання загальних завдань, поставлених перед ними. У разі ж взаємодії не спостерігається наявність владних та підпорядкованих повноважень, усі суб'єкти спільної діяльності рівні між собою. Приєднуємося до позиції М. П. Бублія, який зазначає, що «наслідком координації є взаємодія тих 
чи інших складових системи, тобто взаємодія виступає наслідком такої управлінської діяльності, як координація. Проте в деяких випадках вони можуть досить глибоко переплітатись і слугувати разом як один управлінський елемент» [10].

Вважаємо за доцільне зупинитися саме на з'ясуванні сутності координаційних органів, характеристиці їхньої специфіки як суб'єктів управлінського впливу. Варто звернути увагу, що у наукових колах питанню з'ясування змісту категорії «координаційні органи» практично не приділено уваги.

На нашу думку, під координаційними органами слід розуміти органи державної влади (інституції), наділені нормами національного адміністративного законодавства повноваженнями щодо узгодження діяльності учасників процесу управління в окремих сфеpax суспільного життя шляхом упорядкування їх взаємозв'язків та взаємодії у напрямі об'єднання зусиль для вирішення спільних завдань.

Метою координації є створення відповідного режиму відносин між суб'єктами, за якого виконання ними узгоджених завдань досягається 3 найменшими витратами сил, засобів та часу, а мета взаємодії полягає в здійсненні певних узгоджених дій, спрямованих на досягнення певного результату [11, с. 54]. Зважаючи на це, на нашу думку, головною метою діяльності координаційних органів є підвищення якісних характеристик рішень, що спільно розробляються і виконуються органами влади та орієнтовані на досягнення заданих результатів. Для досягнення поставленої мети кожен учасник координаційних заходів застосовує в рамках наданої йому компетенції форми та методи в одному узгодженому напрямі спільно $з$ іншими органами.

Основним призначенням діяльності координаційних органів є упорядкування діяльності органів виконавчої влади щодо реалізації державної політики у відповідних сферах суспільного життя. Наведемо приклади таких координаційних органів та сфери, для забезпечення належного функціонування яких вони мають право реалізовувати координаційні заходи:

- Рада національної безпеки і оборони України, яка відповідно до Конституції України $€$ координаційним органом з питань національної безпеки і оборони при Президентові України [12];

- Антитерористичний центр при Службі безпеки України, який здійснює координацію діяльності суб'єктів боротьби з тероризмом у запобіганні терористичним актам щодо державних діячів, критичних об'єктів життєзабезпечення населення, об’єктів підвищеної небез- пеки, актам, що загрожують життю і здоров'ю значної кількості людей, та їх припиненні [13];

- Координаційна рада з питань реформування державного управління, яка є тимчасовим консультативно-дорадчим органом Кабінету Міністрів України, утвореним з метою забезпечення координації заходів 3 розроблення проектів та реалізації Стратегії реформування державного управління на період до 2021 року та Стратегії реформування системи управління державними фінансами на 20172020 роки [14];

- Координаційна рада 3 питань реалізації в Україні Ініціативи «Партнерство «Відкритий Уряд», яка є тимчасовим консультативнодорадчим органом Кабінету Міністрів України, діяльність якого спрямована на забезпечення координації заходів з реалізації Ініціативи «Партнерство «Відкритий Уряд» в Україні, залучення до реалізації Ініціативи інститутів громадянського суспільства [15];

- Координаційна рада 3 питань професійного навчання державних службовців, голів місцевих державних адміністрацій, їх перших заступників та заступників, посадових осіб місцевого самоврядування, депутатів місцевих рад при Національному агентстві України 3 питань державної служби [16];

- Координаційна рада $з$ питань впровадження реформи у сфері освіти, яка є тимчасовим консультативно-дорадчим органом Кабінету Міністрів України, утвореним 3 метою вивчення проблемних питань, пов'язаних 3 реалізацією державної політики 3 впровадження реформи у сфері освіти [17];

- Координаційна рада 3 питань розвитку мікропідприємництва та малого підприємництва, яка є тимчасовим консультативно-дорадчим органом, утвореним з метою покращення умов для розвитку підприємництва, провадження фізичними особами підприємницької діяльності [18];

- Міжвідомча координаційна рада з питань правосуддя щодо неповнолітніх, яка є тимчасовим консультативно-дорадчим органом Кабінету Міністрів України, утвореним з метою запровадження міжінституційної платформи для системного обговорення та вирішення проблемних питань розвитку правосуддя щодо неповнолітніх, прийняття узгоджених рішень, що відповідають інтересам дитини [19];

- Координаційна рада сприяння розвитку громадянського суспільства, яка є консультативно-дорадчим органом при Президентові України, створеним з метою сприяння налагодженню конструктивної взаємодії державних органів, органів місцевого самоврядування з організаціями громадянського суспільства, формування сприятливого середовища для посилення ролі громадянського суспільства, 
залучення потенціалу його організацій до процесів формування та реалізації державної, регіональної політики, вирішення питань місцевого значення, механізмів сприяння розвитку в Україні громадянського суспільства [20].

Звісно, це не вичерпний перелік координаційних органів, які створені та функціонують на території України.

У результаті аналізу нормативно-правових актів, в яких окреслено коло повноважень координаційних органів, можна дійти висновку, що вказані органи під час реалізації державної політики уповноважені вживати такі заходи:

- визначати порядок роботи учасників узгодженої діяльності;

- упорядковувати черговість заходів;

- визначати коло безпосередніх учасників координаційних заходів;

- визначати коло осіб, відповідальних за здійснення контролю за виконанням окремих заходів;

- отримувати в установленому порядку необхідну інформацію, документи та матеріали від інших учасників спільної діяльності;

- утворювати в разі потреби для виконання покладених на них завдань постійні або тимчасові робочі групи;

- визначати механізм оцінювання ефективності реалізації передбачених заходів, виявляти причини та умови, що зумовили недостатню ефективність виконання заходів (або невиконання взагалі), та вживати заходів щодо недопущення виникнення таких ситуацій у майбутньому;

- організовувати і проводити конференції, засідання, форуми, наради, зустрічі, семінари з питань, що належать до їх компетенції;

- у рамках наданих повноважень виконувати інші специфічні завдання залежно від ситуації, що склалася.

Зважаючи на це, на координаційні органи, які виконують надані їм координаційні повноваження у відповідних сферах суспільного життя, покладається обов'язок:

- аналізу (моніторингу) стану виконання іншими учасниками спільної діяльності покладених на них обов'язків, сприяння здійсненню інформаційно-аналітичного супроводу;

- оперативного розгляду питань, що належать до їхньої компетенції, підготовки пропозицій щодо усунення виявлених недоліків (вироблення альтернативних варіантів їх розв'язання);

- створення умов для ефективного та раціонального використання наявних у них сил та засобів;

- підготовки за результатами своєї роботи звітів, пропозицій та рекомендацій.
Організаційною формою роботи координаційних органів є засідання, які проводяться за рішенням керівників у міру необхідності, але не рідше одного разу на місяць.

Під час виконання покладених на них завдань координаційні органи взаємодіють з іншими державними органами, органами місцевого самоврядування, підприємствами, установами та організаціями, інституціями громадянського суспільства.

\section{Висновки}

Підсумовуючи викладене вище, можна дійти висновку, що основними ознаками діяльності координаційних органів як суб'єктів реалізації державної політики є:

- врегульована нормами адміністративного законодавства (має правовий характер);

- узгоджуються дії суб'єктів спільної діяльності за цілями, часом, місцем проведення, коло виконавців та програма заходів з урахуванням компетенції кожного виконавця;

- характеризується наявністю процесуально-процедурних аспектів;

- зумовлена об'єктивними потребами, здійснюється на постійній основі в інтересах суспільства та держави в цілому;

- здійснюється спеціально уповноваженими на те суб'єктами по відношенню до тих учасників, що не перебувають у відносинах прямого підпорядкування 3 координуючим суб'єктом;

- здійснюється в чітко визначених формах та способах у межах повноважень координуючого суб'єкта.

\section{Список використаних джерел:}

1. Безпалова О. І. Адміністративно-правовий механізм реалізації правоохоронної функції держави : монографія. Харків : НікаНова, 2014. 544 с.

2. Деякі питання реформування державного управління України : Розпорядження Кабінету Міністрів України від 24.06.2016 p. № 474. URL: https://zakon.rada. gov.ua/laws/show/474-2016-\%D1\%80 (дата звернення: 15.05.2020).

3. Маркелов Т. Л. Взаимосвязь органов прокуратуры с общественностью в борьбе с правонарушениями. Проблемы участия общественности в борьбе с преступностью : сб. науч. тр. Москва : Изд-во Всесоюз. ин-та по изучению причин и разработке мер предупреждения преступности, 1978. С. 110-122.

4. Новий тлумачний словник української мови : у 4 т. Т. 1. А-С / уклад. В. В. Яременко, О. М. Сліпушко. Київ : Аконіт, 1998. 910 с.

5. Бараш Є. Ю. Організаційно-правові засади діяльності установ виконання покарань : дис. ... канд. юрид. наук : 12.00.07. Харків, 2006. 232 с.

6. Борисов А.Б. Большой экономический словарь. Москва : Книжный мир, 2003. 895 с. 
7. Социальное управление : словарь / под. ред. В. И. Добренькова, И. М. Слепенкова. Москва: Изд-во МГУ, 1994. 361 с.

8. Сівков С. «Взаємодія» i «координація»: масштабність понять. Закон и жизнь. 2013. № 6. С. $27-29$.

9. Білоус В. Т. Координація боротьби з економічною злочинністю : монографія. Ірпінь : Академія держ. подат. служби, 2012. 449 с.

10. Бублій М.П. Координація діяльності органів державної влади під час здійснення контрольних функцій. Теорія та практика державного управління. Вип. 3(42). URL: http://www.kbuapa kharkov.ua/e-book/tpdu/2013-3/doc/1/03.pdf (дата звернення: 15.05.2020).

11. Заброда Д. Г. Взаємодія суб'єктів боротьби 3 корупцією (адміністративно-правовий аспект) дис. ... канд.. юрид. наук : 12.00 .07 / Д. Г. Заброда. К., 2005. 235 c

12. Про Раду національної безпеки i оборони України : Закон України від 05.03.1998 p. № 183. URL: https://zakon.rada.gov. ua/laws/show/183/98-\%D0\%B2\%D1\%80 (дата звернення: 15.05.2020)

13. Про Положення про Антитерористичний центр та його координаційні групи при регіональних органах Служби безпеки України : Указ Президента України від 14.04.1999 р. № 379. URL: https://zakon.rada.gov.ua/laws/show/183/98\%D0\%B2\%D1\%80 (дата звернення: 15.05.2020).

14. Про Координаційну радуз питань реформування державного управління: Постанова Кабінету Міністрів України від 18.05.2016 р. № 335. URL: https://zakon.rada.gov.ua/laws/show/335-2016\% D0\%BF (дата звернення: 16.05.2020).

15. Деякі питання реалізації в Україні Ініціативи "Партнерство "Відкритий Уряд" : Постанова Кабінету Міністрів України від 13.06.2012 р.
№ 671. URL: https://zakon.rada.gov.ua/laws/ show $/ 671-2012-\% \mathrm{D} 0 \% \mathrm{BF}$ (дата звернення: 17.05.2020)

16. Про утворення Координаційної ради 3 питань професійного навчання державних службовців, голів місцевих державних адміністрацій, їх перших заступників та заступників, посадових осіб місцевого самоврядування, депутатів місцевих рад при Національному агентстві України з питань державної служби : Наказ Національного агентства України з питань державної служби України від 30.05.2018 р. № 118. URL: https:// ips.ligazakon.net/document/view/FN043129 (дата звернення: 17.05.2020).

17.Про утворення Координаційної ради 3 питань впровадження реформи у сфері освіти : Постанова Кабінету Міністрів України від 27.12.2018 р. № 1203. URL: https:// www.kmu.gov.ua/npas/pro-i-radi-z-pitanvprovadzhennya-reformi-u-sferi-osviti (дата звернення: 17.05.2020).

18. Про утворення Координаційної ради 3 питань розвитку мікропідприємництва та малого підприємництва : Постанова Кабінету Міністрів України від 28.10.2019 р. № 183. URL: https://zakon.rada.gov.ua/laws/show/183/98\%D0\%B2\%D1\%80 (дата звернення: 18.05.2020).

19. Про утворення Міжвідомчої координаційної ради з питань правосуддя щодо неповнолітніх : Постанова Кабінету Міністрів України від 24.05.2017 р. № 357. URL: https://zakon.rada. gov.ua/laws/show/357-2017-\%D0\%BF (дата звернення: 18.05.2020).

20. Питання Координаційної ради сприяння розвитку громадянського суспільства : Указ Президента України від 04.11.2016 р. № 487. URL: https://zakon.rada.gov.ua/laws/ show/487/2016 (дата звернення: 18.05.2020).

Olha Bezpalova. The essence and importance of coordinating bodies as subjects of state policy implementation

It is established that the main purpose of the activities of the coordinating bodies is to streamline the activities of the executive authorities on the implementation of state policy in the respective spheres of public life. Examples of such coordinating bodies and areas are given, to ensure the proper functioning of which they are entitled to implement coordination activities. As a result of the analysis of normative legal acts, which outlines the terms of reference of the coordinating bodies, the circle of measures which these authorities are empowered to take in the implementation of state policy is determined. It is determined that the coordinating bodies should be understood as bodies of state power (institutions), empowered with the norms of national administrative legislation to coordinate the activities of the participants of the process of management in certain spheres of public life by streamlining their relations and interaction in the direction of joining efforts to solve common problems. It has been found that the main purpose of the coordination bodies is to improve the quality characteristics of decisions that are jointly developed and implemented by the authorities and focused on achieving the desired results. In order to achieve this goal, each participant in the coordination activities uses within the competence assigned to it forms and methods in one coordinated direction jointly with other bodies. It is concluded that the main features of the activities of the coordinating bodies as subjects of the implementation of state policy are: regulated by the rules of administrative legislation (has legal character); co-ordinate the actions of the subjects of the joint activity by purpose, time, venue, circle of performers and program of actions taking into account the competence of each performer; characterized by the presence of procedural and procedural aspects; conditioned by objective needs, carried out on an ongoing basis for the benefit of society and the state as a whole; carried out by specially authorized entities in relation to those participants who are not in direct subordination with the coordinating entity; carried out in clearly defined forms and ways within the authority of the coordinating entity.

Key words: coordination, interaction, management function, coordination bodies, coordination activities, actors, public policy. 